\title{
Life quality and human capital within reproduction system: regional aspect
}

\author{
Lyudmila Makarova ${ }^{1}$, Elena Tkach $^{1,{ }^{*}, \text { Irina } \text { Kudryavtseva }^{1}, \text { Anna Seliverstova }}{ }^{1}$ and Natalya \\ Vinogradova $^{2}$ \\ ${ }^{1}$ Faculty of Economics, Chelyabinsk State University, Chelyabinsk 454001, Russian Federation \\ ${ }^{2}$ Department of Economics, Kostanay Social and Technical University, Kostanay 110010, Kazakhstan
}

\begin{abstract}
Human capital as a national economy defining basic factor is considered in the article. The research is focused on human capital study based on regional level. The correlation between human capital and quality of life is also revealed in the study. The quality of life correlates with the model of the society and the dominating model of a human. The major importance of the qualify of life is considered within the concept of sustainable development. The observation of a trend of a human life quality improvement and, therefore, human capital enrichment is presented on a scheme below. Analysis and evaluation of a human capital of a region is provided within historical and modern aspects.
\end{abstract}

\section{Introduction}

The level of human capital development is a basic factor defining the state of national economy. Theoretical basis of a human capital concept was developed in research of Jacob Mincer [1, 2, 3], etc. Researches consider human capital on a signal person level, enterprise level, regional level, national level.

Due to the purpose of the study, we consider human capital category as a combination of concentration of human resources on a territory that possess accumulated knowledge, abilities, professional skills, health condition, cultural level. [4]

The quality of life and human capital are the major characteristics of the development of human science.

The quality of life is correlated with the model of the society and the dominating model of a human in the society. A model of a human is a simplified idea of a person that represents his motivation for economic activity, purposes, cognitive abilities used for goals attainment. Thus, a "consumer" is the major actor of a market society. At the same time material goods and pleasure define the quality of life of a "consumer". The level of consumption depends directly on the amount of money that allows a "consumer" to meet their demands.

In case we consider the model of human within market socioeconomic system, the quality of life of a human is defined by the quantity of material goods consumed. The level of consumption is defined the quantity of money, the source of money does not matter. The

* Corresponding author: author@email.org 
dominance of such "economic" human model leads to significant negative outcomes. In the pursuit of better quality of life, people consume more material goods. It led to economic disaster. Therefore, it led to reevaluation of people's values, values of the society and other basic criteria of the quality of life.

Within the concept of sustainable development, an important aspect of human capital reproduction is considered to be a focus on developing demands. Fulfilling such demands illustrates the improvement of the quality of life itself. Moreover, there is no need to impose limits for developing needs of people in order to eliminate the major contradiction of modern economy between unlimited needs and limited resources.

In context of human transition into innovative path of development, the concept is important. Human intellect, their knowledge and skills became the major reason for economic growth. Within new economic conditions, human capital reproduction cost became an investment instead of expenses. The more resources people investe in healthcare, education, science and culture, the more the quality of human capital increase. Therefore, there are more opportunities for economic growth. Nevertheless, the idea could be implemented only in context of necessary developing human needs.

Maslow's hierarchy of needs is used to reveal human tendency towards the improvement of quality of life and, consequently, the enrichment of human capital. (Figure 1):

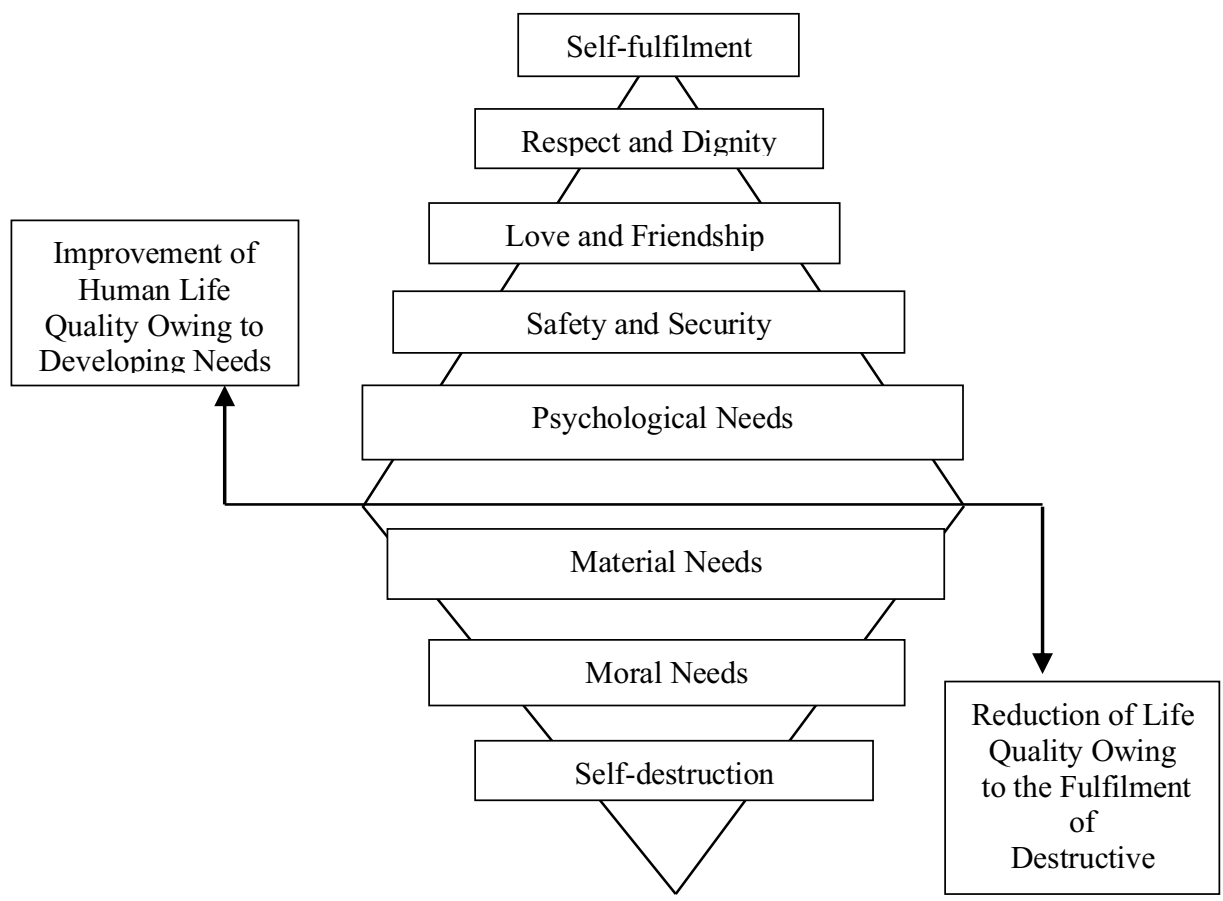

Fig. 1. The demands impact on human life quality

Necessary quality of life of working force is an important aspect of the working potential reproduction process including their working force and human capital as well. The improvement of life quality by fulfillment of developing needs leads to the enrichment of human capital. On the contrary, decrease in life quality because of fulfillment of destructive needs leads to decrease of human capital. 
System approach to the quality of life analysis proposes to consider the quality of human life as subsystem of reproduction process quality on society level within social system. Furthermore, the process of life quality management is based on society reproduction management guided by moral and cultural type and material (economic) type of reproduction considered via category of quality. Human capital implies investments in a human development and improvement of their life quality.

A "human capital" category is deeply researched in economic science. We consider that the research on correlation of human capital reproduction and their territory budget is important.

A qualify of life is mostly defined by a territorial level because a territory provides conditions needed for a human activity, both personal and professional skills. Therefore, human capital reproduction on a territorial level is among major issues of economic science [5-15]. The major objects of social infrastructure are located on a defined territory. Necessary conditions for a balanced comprehensive individual development are also implemented on a certain territory.

\section{Impact of the territorial budget expenditures on human capital}

Numerous researchers were focusing on evaluation of indicators representing various aspects of human capital formations and development [16-18].

According to significance and importance of social expenditures in context of budget policy implementation and its impact on human capital evaluation, the following indication might be introduced (Table 1):

Table 1. The impact of territorial budget expenditures on territory's human capital reproduction

\begin{tabular}{|c|c|}
\hline Indicator & Formula for calculating \\
\hline $\begin{array}{l}\text { Share of social expenditures within territorial } \\
\text { budget total costs }\end{array}$ & $\begin{array}{l}\text { Expenditures on social sphere / } \\
\text { Total expenditures }\end{array}$ \\
\hline Social expenditures per capita & $\begin{array}{c}\text { Expenditures on social sphere / } \\
\text { Population }\end{array}$ \\
\hline $\begin{array}{l}\text { Share of expenditures on healthcare within } \\
\text { territorial budget total costs }\end{array}$ & $\begin{array}{c}\text { Expenditures on healthcare / } \\
\text { Total expenditures on social sphere }\end{array}$ \\
\hline Expenditures on healthcare per capita & $\begin{array}{c}\text { Expenditures on healthcare / } \\
\text { Population }\end{array}$ \\
\hline $\begin{array}{l}\text { Share of expenditures on education within } \\
\text { territorial budget total costs }\end{array}$ & $\begin{array}{c}\text { Expenditures on education / } \\
\text { Total expenditures on social sphere }\end{array}$ \\
\hline Expenditures on education per capita & $\begin{array}{c}\text { Expenditures on education / } \\
\text { Population }\end{array}$ \\
\hline $\begin{array}{l}\text { Share of expenditures on culture and mass } \\
\text { media within territorial budget total costs }\end{array}$ & $\begin{array}{l}\text { Expenditures on culture and mass media / Total } \\
\text { expenditures on social sphere }\end{array}$ \\
\hline $\begin{array}{l}\text { Expenditures on culture and mass media per } \\
\text { capita }\end{array}$ & $\begin{array}{c}\text { Expenditures on culture and mass media / } \\
\text { Population }\end{array}$ \\
\hline $\begin{array}{l}\text { Share of expenditures on social welfare } \\
\text { within territorial budget total costs }\end{array}$ & $\begin{array}{l}\text { Expenditures on social welfare / } \\
\text { Total expenditures on social sphere }\end{array}$ \\
\hline Expenditures on social welfare per capita & $\begin{array}{c}\text { Expenditures on social welfare / } \\
\text { Population }\end{array}$ \\
\hline $\begin{array}{l}\text { Share of expenditures on physical education } \\
\text { and sports within territorial budget total costs }\end{array}$ & $\begin{array}{l}\text { Expenditures on physical education and sports / } \\
\text { Total expenditures on social sphere }\end{array}$ \\
\hline $\begin{array}{l}\text { Expenditures on physical education and } \\
\text { sports per capita }\end{array}$ & $\begin{array}{l}\text { Expenditures on physical education and sports / } \\
\text { Population }\end{array}$ \\
\hline
\end{tabular}

During the period from 1971 to 1980 Chelyabinsk population exceeded one million people. According to Bakanov S.A., this period merits special focus. Due to statistical data, 
Chelyabinsk population comprised 875,2 thousand people in 1970; 989,1 thousand people in 1976; 1032,1 thousand people in 1977; 1067,1 thousand people in 1980 respectively. Consequently, population growth comprised 121,9\% during 1971-1980 [19]

Furthermore, let us consider the way Chelyabinsk city budget expenditures on sociocultural events have changed during that period and compare the data with the USSR local budget statistical data (Table 2):

Table 2. Expenditures of both the USSR local budgets and Chelyabinsk city budget on socio-cultural events in 1971-1980

\begin{tabular}{|c|c|c|c|c|c|c|c|c|c|c|}
\hline & \multicolumn{2}{|c|}{1971} & \multicolumn{2}{|c|}{1972} & \multicolumn{2}{|c|}{1973} & \multicolumn{2}{|c|}{1974} & \multicolumn{2}{|c|}{1975} \\
\hline $\begin{array}{l}\text { Expendi } \\
\text { tures on } \\
\text { Socio- } \\
\text { Cultural } \\
\text { Events }\end{array}$ & Total & $\begin{array}{c}\text { Perc } \\
\text { enta } \\
\text { ge } \\
\% \%\end{array}$ & Total & $\begin{array}{c}\text { Perc } \\
\text { enta } \\
\text { ge } \\
\% \%\end{array}$ & Total & $\begin{array}{c}\text { Perc } \\
\text { enta } \\
\text { ge } \\
\% \%\end{array}$ & Total & $\begin{array}{c}\text { Percen } \\
\text { tage } \\
\% \%\end{array}$ & Total & $\begin{array}{c}\text { Perc } \\
\text { enta } \\
\text { ge } \\
\% \%\end{array}$ \\
\hline $\begin{array}{l}\text { USSR } \\
\text { Local } \\
\text { Budgets } \\
\text { mln rub }\end{array}$ & 20232 & 66,5 & 21242 & 66,0 & 22579 & 67,1 & 23617 & 64,9 & 24687 & 65,7 \\
\hline $\begin{array}{l}\text { Chelyab } \\
\text { insk } \\
\text { City } \\
\text { Budget, } \\
\text { thsd rub }\end{array}$ & 61,4 & 58,7 & 62,8 & 56,9 & 67,0 & 62,9 & 70,4 & 61,9 & 71,9 & 58,1 \\
\hline & \multicolumn{2}{|c|}{1976} & \multicolumn{2}{|c|}{1977} & \multicolumn{2}{|c|}{1978} & \multicolumn{2}{|c|}{1979} & \multicolumn{2}{|c|}{1980} \\
\hline $\begin{array}{l}\text { Expendi } \\
\text { tures on } \\
\text { Socio- } \\
\text { Cultural } \\
\text { Events }\end{array}$ & Total & $\begin{array}{c}\text { Perc } \\
\text { enta } \\
\text { ge } \\
\% \%\end{array}$ & Total & $\begin{array}{c}\text { Perc } \\
\text { enta } \\
\text { ge } \\
\% \%\end{array}$ & Total & $\begin{array}{c}\text { Perc } \\
\text { enta } \\
\text { ge } \\
\% \%\end{array}$ & Total & $\begin{array}{c}\text { Percen } \\
\text { tage } \\
\% \%\end{array}$ & Total & $\begin{array}{c}\text { Perc } \\
\text { enta } \\
\text { ge } \\
\% \%\end{array}$ \\
\hline $\begin{array}{l}\text { USSR } \\
\text { Local } \\
\text { Budget, } \\
\text { mln rub }\end{array}$ & 25428 & 64,0 & 26412 & 62,3 & 28004 & 63,0 & 28939 & 63,3 & 30068 & 63,4 \\
\hline $\begin{array}{l}\text { Chelyab } \\
\text { insk } \\
\text { City } \\
\text { Budget, } \\
\text { thsd rub }\end{array}$ & 73,4 & 58,7 & 78,3 & 57,4 & 78,6 & 57,7 & 88,4 & 66,7 & 88,6 & 60,9 \\
\hline
\end{tabular}

Therefore, the share of Chelyabinsk city budget expenditures on socio-cultural events comprised 58-62\% while expenditures on the same industry in other USSR regions comprised approximately $63-65 \%$. Overall, during the decade local budget expenditures on socio-cultural events in different USSR regions comprised 251208,9 mil rubble and 64,3\% of total budget expenditures. Chelyabinsk city budget expenditures on the same field comprised $740665,6 \mathrm{mln}$ rubble and $60 \%$ of total budget expenditures. Consequently, share of Chelyabinsk budget expenditures on socio-cultural events is $4 \%$ less than indexes of other regions. Generally, this cost type within the USSR governmental expenditures comprised $35,1 \%$. Therefore, it might be concluded that local budget expenditures were socially oriented.

Let us analyse the dynamics of Chelyabinsk city budget expenditures on socio-cultural events in 1970-1980s due to the algorithm presented on the table 3. 
Table 3. Chelyabinsk city budget expenditures on socio-cultural events since 1971 till 1980 (thousand rubble)

\begin{tabular}{|c|c|c|c|c|c|c|c|c|}
\hline \multirow{9}{*}{$\begin{array}{l}\text { Chelyabinsk } \\
\text { City Budget } \\
\text { Expenditures } \\
\text { on Socio- } \\
\text { Cultural } \\
\text { Events }\end{array}$} & \multicolumn{2}{|c|}{1971} & \multicolumn{2}{|c|}{1972} & \multicolumn{2}{|c|}{1973} & \multicolumn{2}{|c|}{1974} \\
\hline & $\begin{array}{c}\text { Total, } \\
\text { mln rub }\end{array}$ & $\begin{array}{c}\text { Growt } \\
\text { h Rate } \\
\% \%\end{array}$ & $\begin{array}{l}\text { Total, } \\
\text { mln rub }\end{array}$ & $\begin{array}{c}\text { Growt } \\
\text { h Rate } \\
\% \%\end{array}$ & $\begin{array}{l}\text { Total, } \\
\text { mln rub }\end{array}$ & $\begin{array}{c}\text { Growt } \\
\text { h Rate } \\
\% \%\end{array}$ & $\begin{array}{c}\text { Total, } \\
\text { mln rub }\end{array}$ & $\begin{array}{c}\text { Grow } \\
\text { th } \\
\text { Rate } \\
\% \%\end{array}$ \\
\hline & 61355 & 100 & 62779 & 102,3 & 67019 & 106,8 & 70424 & 105,1 \\
\hline & \multicolumn{2}{|c|}{1975} & \multicolumn{2}{|c|}{1976} & \multicolumn{2}{|c|}{1977} & \multicolumn{2}{|c|}{1978} \\
\hline & $\begin{array}{l}\text { Total, } \\
\text { mln rub }\end{array}$ & $\begin{array}{c}\text { Growt } \\
\text { h Rate } \\
\% \%\end{array}$ & $\begin{array}{l}\text { Total, } \\
\text { mln rub }\end{array}$ & $\begin{array}{c}\text { Growt } \\
\text { h Rate } \\
\% \%\end{array}$ & $\begin{array}{l}\text { Total, } \\
\text { mln rub }\end{array}$ & $\begin{array}{c}\text { Growt } \\
\text { h Rate } \\
\% \%\end{array}$ & $\begin{array}{l}\text { Total, } \\
\text { mln rub }\end{array}$ & 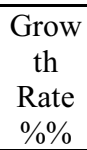 \\
\hline & 71858 & 102,0 & 73394 & 102,1 & 78341 & 106,7 & 78558 & 100,3 \\
\hline & \multicolumn{4}{|c|}{1979} & \multicolumn{4}{|c|}{1980} \\
\hline & \multicolumn{2}{|c|}{ Total, mln rub } & \multicolumn{2}{|c|}{$\begin{array}{c}\text { Growth Rate } \\
\% \% \\
\end{array}$} & \multicolumn{2}{|c|}{ Total, mln rub } & \multicolumn{2}{|c|}{$\begin{array}{c}\text { Growth Rate } \\
\% \% 1 \\
\end{array}$} \\
\hline & \multicolumn{2}{|c|}{88380,4} & \multicolumn{2}{|c|}{112,5} & \multicolumn{2}{|c|}{88557,9} & \multicolumn{2}{|c|}{100,2} \\
\hline
\end{tabular}

According to the data shown above, there is a positive trend in Chelyabinsk city budget expenditures on both in general and on socio-cultural events. On the average, it was increasing 3,8\% annually. During the period of 1970-1980s Chelyabinsk city budget expenditures increased $44 \%$ in comparison to $48,6 \%$ in case of the USSR local budget expenditures.

Let us analyse the dynamics of Chelyabinsk city budget expenditures on social sphere during the period of 2009-2018 using the approach implemented above (Table 4):

Table 4. Chelyabinsk city budget expenditures on social sphere in 2009-2018

\begin{tabular}{|c|c|c|c|c|c|c|c|c|}
\hline \multirow{9}{*}{$\begin{array}{l}\text { Chelyabinsk } \\
\text { City Budget } \\
\text { Expenditures } \\
\text { on Social } \\
\text { Sphere }\end{array}$} & \multicolumn{2}{|c|}{2009} & \multicolumn{2}{|c|}{2010} & \multicolumn{2}{|c|}{2011} & \multicolumn{2}{|c|}{2012} \\
\hline & $\begin{array}{l}\text { Total, } \\
\text { mln rub }\end{array}$ & $\begin{array}{l}\text { Growth } \\
\text { Rate } \\
\% \%\end{array}$ & $\begin{array}{c}\text { Total, } \\
\text { mln } \\
\text { rub }\end{array}$ & $\begin{array}{l}\text { Growth } \\
\text { Rate } \\
\% \%\end{array}$ & $\begin{array}{l}\text { Total, } \\
\text { mln } \\
\text { rub }\end{array}$ & $\begin{array}{l}\text { Growth } \\
\text { Rate } \\
\% \%\end{array}$ & $\begin{array}{l}\text { Total, } \\
\text { mln } \\
\text { rub }\end{array}$ & $\begin{array}{c}\text { Growth } \\
\text { Rate } \\
\% \%\end{array}$ \\
\hline & 11055 & 100 & 14245 & 128,9 & 17110 & 120,1 & 18415 & 118,7 \\
\hline & \multicolumn{2}{|c|}{2013} & \multicolumn{2}{|c|}{2014} & \multicolumn{2}{|c|}{2015} & \multicolumn{2}{|c|}{2016} \\
\hline & $\begin{array}{c}\text { Growth } \\
\text { Rate } \\
\% \%\end{array}$ & $\begin{array}{l}\text { Total, } \\
\text { mln } \\
\text { rub }\end{array}$ & $\begin{array}{c}\text { Total, } \\
\text { mln } \\
\text { rub }\end{array}$ & $\begin{array}{c}\text { Growth } \\
\text { Rate } \\
\% \%\end{array}$ & $\begin{array}{l}\text { Total, } \\
\text { mln } \\
\text { rub }\end{array}$ & $\begin{array}{c}\text { Growth } \\
\text { Rate } \\
\% \%\end{array}$ & $\begin{array}{c}\text { Total, } \\
\text { mln } \\
\text { rub }\end{array}$ & $\begin{array}{c}\text { Growth } \\
\text { Rate } \\
\% \%\end{array}$ \\
\hline & 21860 & 118,7 & 23055 & 105,4 & 23481 & 101,8 & 25113 & 107,0 \\
\hline & \multicolumn{4}{|c|}{2017} & \multicolumn{4}{|c|}{2018} \\
\hline & \multicolumn{2}{|c|}{ Total, mln rub } & \multicolumn{2}{|c|}{$\begin{array}{c}\text { Growth Rate } \\
\% \% \\
\end{array}$} & \multicolumn{2}{|c|}{ Total, mln rub } & \multicolumn{2}{|c|}{$\begin{array}{c}\text { Growth Rate } \\
\% \% \\
\end{array}$} \\
\hline & \multicolumn{2}{|c|}{26097} & \multicolumn{2}{|c|}{103,9} & \multicolumn{2}{|c|}{29486} & \multicolumn{2}{|c|}{113,0} \\
\hline
\end{tabular}

According to the figures shown above, Chelyabinsk city budget expenditures on social sphere increased almost three times from 11 bln rub till 29,5 bln rub during 2009-2018. Nevertheless, the growth was not stable and remained on low level some years. For example, it comprised $101,8 \%$ in 2015 and $128,9 \%$ in 2010 in comparison to the previous year. On the average, the growth rate comprised about $10 \%$ during the decade. Furthermore, let us evaluate the structure of Chelyabinsk city budget expenditures on social sphere, compared to 1977.

The results of the reports indicate the share of social expenditures within Chelyabinsk city budget total expenditures in 2014 are comparable with the results of 1977 (58,7\% and $60,4 \%$ respectively), but during 2014-2018 the index has increased significantly on average 
$17,9 \%$. In addition to that, the share of expenditures on education has increased more than 2,5 times in comparison to 1977. The share of expenditures on culture and social welfare has increased 3,3 and 52,5 times respectively in comparison to 1977. The growth shown stimulates reproduction of human capital but a range of deterring factors constrains it. To start with, there is a significant decrease in share of expenditures on healthcare within total social expenditures. Expenditures on healthcare comprised 32,7\% in 1977 in comparison to $2,27 \%$ in 2018. Furthermore, expenditures on environmental protection do not change actually and comprise not more than $0,2 \%$ within total social expenditures.

The authors conclude that evident increase in expenditures on social sphere both in dynamics and structure demonstrates budget allocation to such human capital reproduction stages as formation and distribution while the stages of exploitation and development stay hidden and requires more focus from authorities and city management.

\section{Conclusion}

The study of human capital reproduction on a territorial level is growing in importance in modern economic science. The process of human capital reproduction takes place on some certain territory. Consequently, comparison of correlation between territorial budget and human capital reproduction in various historical conditions is of interest. The common approach in the form of algorithm of various historical periods comparison was developed. The authors of the study presented a structured logical paradigm of correlation of different stages of human capital reproduction and budget flows on a certain territory.

During the study the increase of Chelyabinsk budget expenditure growth pace on social sphere was revealed. Thus, though in 1970-1980s annual growth rate was 3-3,5\% per year, in 2009-2018 annual growth rate increased till 10\% approximately. Furthermore, the structure of the city budget has changed. The share of expenditures on social sphere has noticeably increased within city budget total expenditures. Thus in 1977 and 2014 the share of expenditures on social sphere comprised about $60 \%$, but since 2014 till 2018 the share of such expenditures increased as much as a quarter and reached $75 \%$. the largest increased has been accounted for educational and cultural industries.

The authors highlights that despite the significant increase of city budget expenditures on social sphere, there are certain factors deterring the growth of effectiveness and qualitative development of human capital. Environmental issues, population decline, migratory exodus of young people to other regions are among the huge range of issues influencing human capital reproduction.

In order to solve accumulated issues and contradictions, the authors suggest the improvement of budget mechanism relying on maximized personification of budget flows due to demands of an individual as a human capital possessor. The authors recommend using the potential of digital economy to personalize territorial budget revenues and expenditures. To implement the idea the authors suggest developing a road map providing the following actions: to develop a personalized database of some territory's human capital; to establish a common expertise in human capital assessment and management and to provide staff with appropriate qualification; to develop the evaluation system of correlation between territorial budget expenditures and human capital.

The further line of research might be the evaluation of effectiveness of budget expenditures on human capital and focusing on the quality of human capital reproduction, especially on the stages of exploitation and development. 


\section{References}

1. J. Mincer. Working Paper of the NBER, 4838 (1994).

2. T. Shultz. Human Capital in the International Encyclopedia of the Social Sciences. (N.Y., 1968).

3. G. Becker. Human Capital. (N.Y.: Columbia University Press, 1964).

4. S.I. Babina, I. Iu. Sadovnikova. Vestnik Kemerovskogo gosudarstvennogo universiteta, 3 (2018). DOI:10.21603/2500-3372-2018-3-69-74

5. M. Squicciarini, N. Voigtländer, (2015). The Quarterly Journal of Economics, 4 (2015).

6. P. Sadeghi, H. Shahrestani, K.Kiani, T. Torabi. Iranian Economic Review, 22 (2018). DOI:10.22059/ier.2018.65359

7. S.V. Grinenko, (2017). Fundamental'nyye issledovaniya [Fundamental research], 6, (2017).

8. M. Belloc, F. Drago, R. Galbiati. CESifo Working Paper Series, 6719 (2019). Available at SSRN: https://ssrn.com/abstract=3098272 (Date of access: 25.03.2021).

9. R. Rocha, C. Ferraz, R.R. Soares. American Economic Journal: Applied Economics, American Economic Association, 4 (2017). DOI: 10.1257/app.20150532

10. S. Marginson. Studies in Higher Education Journal, 44 (2019) DOI: 10.1080/03075079.2017.1359823

11. I. Sycheva, E. Skripleva, A. Dunets, , T. Vorozheykina, I. Luzenina. International Journal of Economics \& Business Administration, 2 (2019).

12. T. Anopchenko, S. Grinenko, E. Edaljva, E. Zadorozhnaya, A. Murzin, ESPACIOS, 39 (2018).

13. E. Lazareva, T. Anopchenko, A. Murzin. Green Technologies and Infrastructure to Enhance Urban Ecosystem Services. Cham, Springer Geography. DOI https://doi.org/10.1007/978-3-030-16091-3_28

14. V.V. Tokareva. The development of human capital at the subregional level (in small cities of Russia). (Michurinsk: MichSAU Publ, 2020).

15. L. Nikitina, (1961). Byudzhetnaya sistema SSSR [The budget system of the USSR]. Kishinev. (Chisinau State University, 1961).

16. V. N. Belkin, N. A. Belkina, O. A. Antonova, N. A. Luzin. Ekonomika regiona, 25 (2011).

17. V. Lokosov, E.Ryumina, V. Ulyanov. Ekonomika regiona, 44 (2015).

18. I. Gurban, A. Myzin. Ekonomika regiona, 32 (2012).

19. S. Bakanov, A.Botova. City, society, environment: history and development vectors. Materials of the All-Russian Scientific and Practical Conference (September 14-15, 2017). 